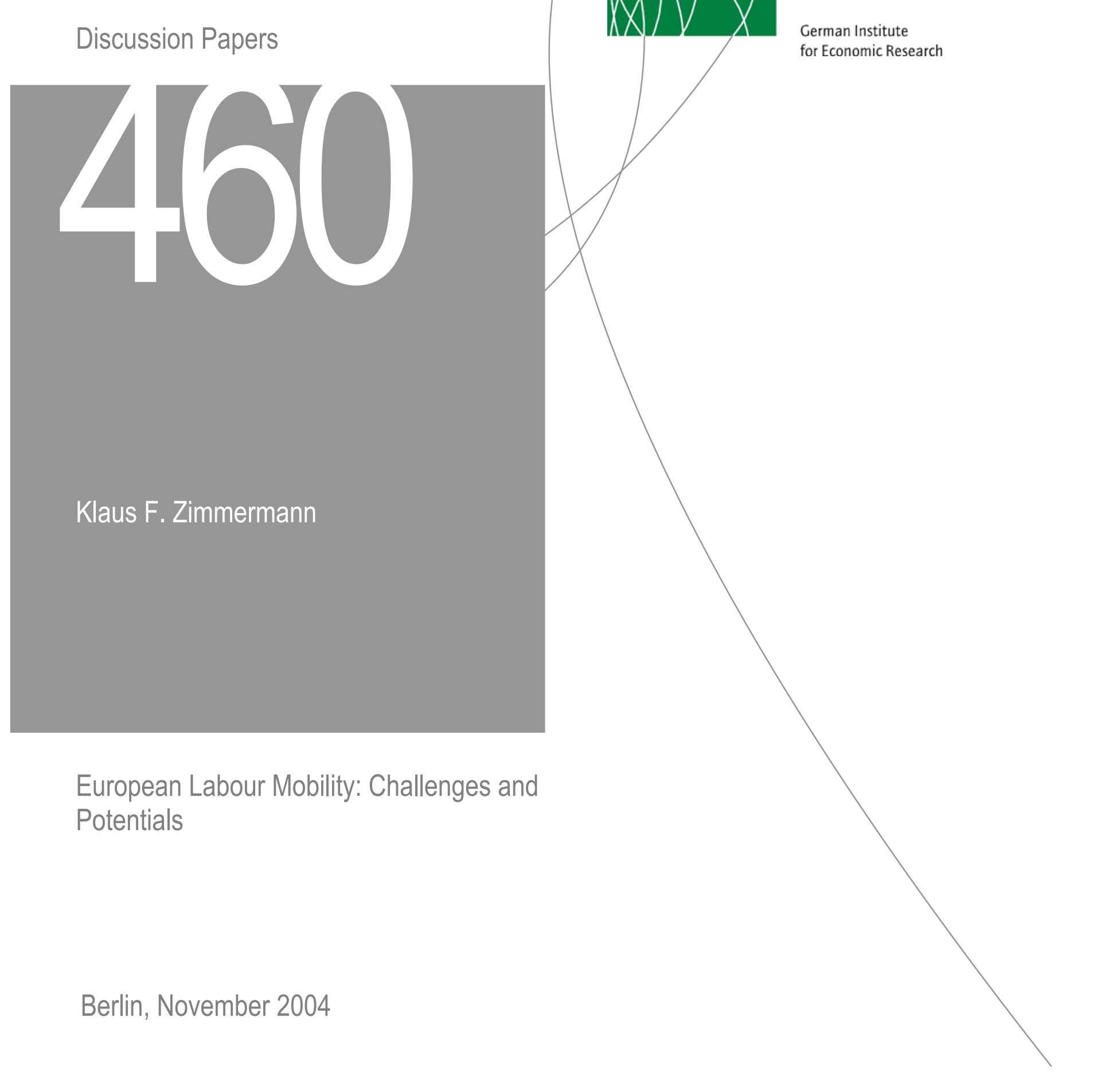


Opinions expressed in this paper are those of the author and do not necessarily reflect views of the Institute.

DIW Berlin

German Institute

for Economic Research

Königin-Luise-Str. 5

14195 Berlin,

Germany

Phone $+49-30-89789-0$

Fax $\quad+49-30-89789-200$

www.diw.de

ISSN 1619-4535 


\title{
European Labour Mobility: Challenges and Potentials
}

\author{
Klaus F. Zimmermann \\ Draft: November 15, 2004
}

\begin{abstract}
European Union economies are pressed by (i) a demographic change that induces population ageing and a decline of the workforce, and (ii) a split labour market that is characterized by high levels of unemployment for low-skilled people and a simultaneous shortage of skilled workers. This lack of flexible high-skilled workers and the aging process has created the image of an immobile labour force and the eurosklerosis phenomenon. In such a situation, an economically motivated immigration policy at the European level can generate welfare improvements. A selective policy that discourages unskilled migrants and attracts skilled foreign workers will vitalize the labour market, foster growth and increase demand for unskilled native workers. The paper summarizes the available economic insights, and suggests (i) the need to harmonize the single-country migration policies across Europe and (ii) that the European Union needs to become an active player on the international labour markets.
\end{abstract}

JEL classification: J61, J21, J68, J82, F22

Keywords: labour mobility, migration, skilled migration, unskilled migration, migration policy, integration policy

* Paper presented at the high-level expert conference "Jobs for Europe" on the Social Policy Agenda for the European Union on October 25-26, 2004 in Amsterdam. The author is President of the German Institute for Economic Research (DIW Berlin), Director of the Institute for the Study of Labor (IZA) in Bonn, Professor of Economics at the University of Bonn, and Honorary Professor at the Free University of Berlin. He thanks Aart Jan Bette, Henk Don, Renske Gerstel, Klara Scheepers, Jan van der Velden and other members of the editorial committee, and Amelie Constant, Don DeVoretz, Holger Hinte and Stephanie Wei Wang for many useful comments on earlier drafts.

Corresponding author:

Klaus F. Zimmermann

IZA, P.O. Box 7240

D-53072 Bonn, Germany

Phone: +49 2283894200

Fax: +49 2283894210 


\section{Kev Challenges and Trends}

Labour inflexibility has been seen for long as the major determinant of the employment crisis and the persistent slump of economic growth in Europe. ${ }^{1}$ In particular, geographical labour mobility has been suggested as a strong instrument to foster fast economic adjustment and growth. It has also been argued that inflexibility of workers might be no problem when internal labour markets within companies would work well. ${ }^{2}$ If there exists substantial firm-specific human capital, inter-firm mobility might be too costly. Also individuals may appreciate inflexibility, because this allows them to live in stable social networks. Consequently, it does not seem surprising that intra-firm job mobility is often more frequent than inter-firm mobility.

While geographical and internal mobility can be both beneficial when employed in a balanced way, migration across regions within a country and between countries within Europe has been in decline over the last decades. ${ }^{3}$ Interregional migration plays a much smaller role in adjustment in Europe than in the United States, and this suggests that this is one important component that drives the relative success of the American economy. Europe has become more inflexible when the pressure to adjust became stronger, but an explanation of this worrying puzzle is that mobility reacts to the availability of jobs. ${ }^{4}$ While economic growth and the creation of new jobs is strongly associated with the willingness to take up chances across regions, the supply of jobs also regulates the flow of people seeking work. Only when a significant rise in economic growth will boost the demand for labour and create new jobs, geographic mobility of natives will rise significantly. Policy measures have hardly a chance to influence this mobility and intra-firm mobility. Hence, immigration from outside the European Union has become a

See OECD (1994), for instance.

See Zimmermann (1998).

See Bauer, Dietz, Zimmermann and Zwintz (2004) for Germany, Faini, Galli, Gennari and Rossi (1997) for Italy and Obstfeld and Peri (1998) for mobility within Europe.

Bauer, Dietz, Zimmermann and Zwintz (2004) make this point to explain the decline in Germany, while Bover and Velilla (2004) show that the recent increase in Spanish mobility is associated with a rise in the availability of jobs. 
potentially very crucial role for the creation of a higher level of labour mobility in Europe. If there is labour mobility it is largely due to international migration.

However, in the globalised world, migration is a controversial and challenging issue. An estimated 175 million people wordwide or about $2.9 \%$ of the world population are currently considered to be international migrants. Among other types of migrants, this number contains people moving for purposes of family reunification, refugees, and displaced persons; only very few are economic migrants. This evaluation ignores illegal migrants who typically come for work Europe is the most important continent for the migration issue showing a current stock of 56 million migrants in the population, followed by Asia with 50 million, and North America with 41 million. In spite of the rising importance of the issue, the understanding of the determinants and the consequences of these movements is still limited, and the proper policy response still unprepared.

Migration challenges can be decomposed into a number of channels. A first channel is unskilled migration. The poor and helpless of the world are knocking at the European doors. Fortress Europe still stands, but at its borders from the East and the South illegal immigration of an unknown size and potential is surging. These aliens contribute to the rising excess supply of native unskilled workers in the European host countries by seeking permanent gainful employment, more and more often with limited success. So far, immigration has not caused much measurable unemployment among natives. However, if current trends prevail, unemployment among immigrants and unskilled native workers may increasingly rise. More social and economic disruptions would be the likely consequence.

A second channel is migration of the most skilled in the labour force. Human capital is the ultimate resource of the 21st century. All developed economies face a strong and increasing excess demand for skilled labour, fostered by technological change, population aging and a subsequent decline in the future native European workforce. The upcoming needs cannot be satisfie d sufficiently by the local labour force or the educational system in the particular 
countries. Europe is more and more drawn into a competition to attract international skilled labour to fill the gaps. However, unlike traditional immigration countries as the United States, Canada or Australia, Europe has no reputation on the international labour markets for highskilled people. Migration, return migration, onward migration and circular migration are the new challenging phenomena in this phase of the internationalisation of the labour market.

A third channel for the global impact of migration on the economy is the required productive mix of skilled and unskilled workers at the workplace. It is increasingly observed that the lack of qualified workers decreases the incentives to hire low -skilled workers. The increasing excess-demand of companies for high-skilled workers is then associated with the growing gap in jobs for the low-skilled. If Europe fails to train enough people or to attract high-skilled labour, there will be soon a pressing need to develop markets that supply jobs for unskilled labour.

Factor mobility is the fourth channel of labour competition. If people do not move or are not allowed to move, trade or capital mobility may take its place. For instance, cheap labour is embodied into the imports of goods, and this threatens home production and low-skilled workers in particular. Virtual migration is the ultimate threat: Many jobs can be exercised through the internet. Companies more and more outsource their jobs by going global. European jobs may thus melt away without any real movement in the foreign work force.

Fifth, the expansion of the European Union will trigger further immigration into major European countries and create new market opportunities in Central and Eas tern Europe. This is, certainly a transition issue, whereas the inflow of low-skilled people has already largely taken place through illegal immigration. Now, the European Union countries need to ensure that the mobile high-skilled East Europeans are not attracted mainly by the traditional immigration countries.

A sixth challenge is that a large part of the current migrants in the European Union are not available for the labour market, since they did not come as economic migrants but through family reunification and as asylum seekers who are not supposed to work. Missing incentives 
and individual characterics of migrants. This is a major policy failure, since Europe as a whole has received large migration flows over the last decades. However, this has been an uncontrolled and unwanted development that has left the union unprepared.

The European Union will soon have to decide how to meet these challenges in an organized, systematic, and collaborative way. Is a continuation of the current policy of neglect still acceptable, or does the European Union need a common labour migration policy that is more pragmatic and "rational" in the sense that it considers economic interests? In order to develop an appropriate policy, it is necessary to learn more about how immigrants currently fare in European member countries, and how they affect the economic well-being of the native populations and public sector finances. It is furthermore important to understand how policy measures have contributed to the current migration situation. Note that while immigration has many dimensions (including social and humanitarian), this paper deals with the issue from a purely economic perspective.

\section{Some Relevant Economic Migration Theories}

Economic theories concerning migration seen from the host country can be organised around three major themes. 5 (i) the determinants of migration, (ii) the assimilation of the migrants, and (iii) the effects of the immigrants on the natives. Migration decisions ${ }^{6}$ respond largely to differences in regional disparities in prosperity. Hence, differences in earnings, unemployment rates, costs of living, public goods and public transfers are important determinants of a move. The decision to move is also affected by the costs of moving that not only include monetary costs like travel expenses, and foregone earnings dur ing the move, but also psychological costs arising from the separation from family and friends. According to the human capital model, the likelihood of migration is decreasing with age, reflecting the smaller expected lifetime gain from moving for older people. Individuals with higher education should exhibit a higher migration

The four volumes by Zimmermann and Bauer (2002) collect the most relevant research papers in the literature outlining the theories of migration, immigrant assimilation and their effects on the natives.

A review of the literature on the migration decision is provided by Bauer and Zimmermann (1998). 
probability, because higher education reduces the risks of migration through a higher ability to collect and process information. The risks and costs of movements are expected to rise with distance, because information about labour market conditions is expected to be better for closer locations. Family issues also typically play an important role. Most migrants move within the context of ethnic networks, resulting in the formation of ethnic clusters in the host country. The mere existence of network and chain migration significantly alleviates the risks and costs and accelerates movement.

How do the migrants fare? This is the question of assimilation and integration into the labour market of the host country. ${ }^{7}$ According to the standard economic models in this field, the degree of assimilation is influenced by individual factors, the characteristics of the home country, the migration motive, and the expected migration duration. The greater the similarity between the sending and the receiving countries in relation to their economic development, the more rapid the assimilation. Individuals who migrate for economic reasons, permanent migrants and those with good knowledge of the language of the host country are expected to assimilate and integrate faster than non-economic and temporary migrants.

A key issue is the international transferability of human capital. Human capital acquired at home may not be fully transferable to the host county. Hence, there is an expected negative relationship between the transferability of human capital and the initial immigrant-native earnings gap. The lower the international transferability of human capital, the higher is the earnings disadvantage of the immigrants at the time of migration. With increasing time of residence in the host country, migrants invest in country-specific human capital of the receiving country and adapt their stock of human capital acquired in the home country. As a consequence, the human capital of the migrants grows relatively faster than the human capital of the natives, and the earnings of the immigrants approach but may not reach those of the natives.

Bauer, Lofstrom and Zimmermann (2000) deal with this issue and incorporate a study of natives' sentiments towards immigrants. Assimilation in an economic sense simply means getting a job an earn as much as natives with identical characteristics. 
How are the natives affected by the migrants $?^{8}$ Crucial here are the conditions on the labour markets of the host country; they might be either competitive or in disequilibrium when labour supply equals labour demand or not, respectively. A further point of departure is that the labour force is heterogeneous and of diverse quality, while it depends on whether immigrants are unskilled or skilled. Disequilibrium situations in labour markets may occur, when there are institutional constraints in the market for unskilled labour such as union wages, minimum wages or transfers like social assistance, or when the educational system is not providing sufficiently fast the necessary supply of workers for the skilled labour markets. Another issue is whether skilled and unskilled workers are complements or substitutes to natives. A reasonable (and standard) assumption is that skilled and unskilled workers are complements.

If there is une mployment among low-skilled workers due to institutional constrain ts like union wages, more unskilled migrants willing to work will make this market more competitive and add also additional jobs for the natives through reduced wages. If immigrants are predominantly unskilled, then they are substitutes for unskilled natives creating friction and complements to skilled natives contributing to their advancement. Accordingly, new immigrants may depress wages and likely increase unemployment of the unskilled workers and may induce the reverse effects for skilled natives. The reverse scenario will occur with skilled immigration. Hence, in a situation of unskilled unemployment and excess demand for skilled work, it makes sense to allow for high-skilled labour migrants.

Institutional constraints on the labour markets, high unemployment among the lowskilled and excess demand for the skilled workers describe the predominant situation in the European Union, currently and in the longer-term future. A selective immigration policy that tends to avoid unskilled migrants and attracts skilled foreign workers will, therefore, be a safe

Borjas (1994) and Bauer and Zimmermann (1997) investigate this issue conceptually, while Borjas (1994) deals with the equilibrium situation only and Bauer and Zimmermann (1997) consider also disequilibrium situations in the labour markets. 
strategy to foster growth, increase demand for unskilled native workers, and be beneficial. This substantiates how migrants can be economically good friends to natives in the labour market.

The policy challenge is to optimize migration to increase welfare by identifying and mobilising the economic component of the process. In a long-term steady-state where migrants are fully assimilated in the sense that they are alike to the natives, with similar human capital and physical capital, there is no real advantage, but also no disadvantage for the host nation. According to standard economic models, the production possibilities are then just shifting outwards with no effects on the income distribution and the welfare levels. However, when migrants are different but in demand, when they bring variety into the labour force, and when they improve the speed of the adjustment of the host economy to its long-run needs, they are of invaluable help.

\section{Empirical Evidence}

This section provides an overview of the rich experiences in Europe of migration regimes, the performance of the migrants and their effects on the native population, which are all well documented in the economic literature. ${ }^{9}$

\subsection{Long -term Migration Policy Regimes Across Europe}

There is a common migration history after World War II across Western European countries. ${ }^{10}$ Europe became one of the main regions for receiving the migrants of the world. There are four relevant phases of post-war migration into Europe; periods of (i) post-war

9 See Faini, de Melo and Zimmermann (1999), Boeri, Hanson and McCormick (2002), Zimmermann and Bauer (2002), Zimmermann (2004), Zimmermann and Constant (2004), Tranaes and Zimmermann (2004), and Venturini (2004). Roodenburg, Euwals and ter Rele (2003) provide findings for the Netherlands. Their analysis of the labour market effects of immigrants is based on a comparison between labour market equilibria before and after immigration, while Bauer and Zimmermann (1997) have also calculated the effects in disequilibrium situations, which are much more substantial.

10 For a deeper analysis of these historical trends see Zimmermann (1995a, 1995b). 
adjustment and decolonisation, (ii) labour migration, (iii) restrained migration, and (iv) dissolution of socialism and afterwards.

The first period covers the years between 1945 and up to the early 1960s. In this period Germany experienced a strong inflow of people displaced by the war. Great Britain, France, Belgium and the Netherlands were affected by return migration from European colonies and the inflow of workers from the former overseas territories. Algerians of French origin were repatriated to France after the independence of Algeria. The Netherlands experienced a large inflow of immigrants from Indonesia in 1946 and 1950. This has been a period of pure supply driven migration.

The second phase of labour migration lasts until the first oil price crisis 1973/74, and was largely motivated by demand factors. The strong economic growth and the resulting labour shortages in the second half of the 1950s and the 1960s induced a number of Western European countries to open up for immigration. Some of the countries even established an active recruitment policy, or guestworker regime. Germany, Austria, the Netherlands, Switzerland, Denmark and Sweden actively recruited unskilled workers from the Southern European countries. Labour migration in this period was mainly motivated by wage differences between the South and the North. Germany and Switzerland opted for temporary migration as a response to labour shortages. However, Switzerland with its rotation principle was more successful than Germany was with the guestworker system. German work contracts and residence permits were supposed to be temporary. However, since these temporary arrangements were not enforced, the guestworker programs resulted in permanent migration. Return migrants to Belgium, the Netherlands, the United Kingdom and France were also permanent, since they were the consequence of decolonisation.

Restrained migration is the third phase of post-war migration into Europe. In the face of increased social tensions and fears about recession after the first oil price shock, the governments all over Europe stopped active recruitment from 1973 onwards. Immigration policies became 
more restrictive affecting labour migrants exclusively. Although the guestworker system was designed for temporary workers, return migration started only slowly. As a consequence, the main channels of immigration became family reunification and humanitarian immigration.

The fourth phase of European migration can be identified at the end of the 1980s, when migration flows to Western Europe were dominated by East-West migration and the inflow of asylum seekers and refugees. Ethnic Germans migrating to Germany played a substantial part in this. Whereas in the 1970s and 1980s, asylum seekers originated mainly from Asia and Africa, the inflow of asylum seekers and refugees from European countries increased significantly in the 1990s, originating in the dissolution of the political regimes in the former socialist states in Eastern Europe. However, also the clashes between Turks and Kurds in the South-East of Turkey generated a substantial number of additional refugees. Around 1992 some European countries, especially Germany, became more restrictive towards the immigration of asylum seekers and refugees. But most European countries did not further restrict their refugee and asylum policies. Sweden, Denmark, the Nethe rlands, France, and Switzerland continued to accept larger numbers of refugees.

Although migration policies were enunciated in different ways across Europe, they have some evident similarities and joint lessons. There were active labour recruitment policies in many countries that have been quite successful to foster economic growth and development; they came to a common halt around the time of the first oil crisis in 1973. However, assimilation policies were not followed or turned out to be not very successful. A temporary migration policy in a general system of regulated migration only works when it is based on a very strict rotation system as in Switzerland. Germany, with its guest worker system, actually received permanent migrants. ${ }^{11}$ Even the French mode 1, with its planned settlements and the Republican assimilation principles ignored the migration dynamics. Family or chain migration has counteracted many

11 This is becaus e of the ban on migration in 1973. If migrants were free to move back and forth, they would not have settled in Germany. 
policy objectives. A crucial phenomenon is return migration. Among economic migrants and within a system of free labour mobility, a large share of migrants return home eventually. However, if borders are closed and labour migration is heavily regula ted, migrants stay in the host country and are followed by their families.

\subsection{Assimilation and Impacts on the Natives}

A large number of studies in the economic literature ${ }^{12}$ have investigated the empirical answers to the key economic questions of immigration: Are migrants taking jobs away and depressing the wages of the natives, or do they contribute to the creation of jobs and increase the general level of wages? Do they adjust to the host country's labour market, in the sense that they work, perform well, as well as natives or even better than natives in the labour marke t? Are they just a burden on the welfare state or do they impart economic gains through increased productivity and higher tax revenues and social security payments?

The Nordic welfare states, especially Denmark and Sweden, do not seem to receive many typical labour migrants. In recent years, the number of non-European migrants has increased mainly due to the immigration of relatives and refugees. First generation migrants are not faring well in comparison to natives, but second generation migrants are becoming more similar to the natives. The relative success of second generation migrants can be traced to the relevance of parental capital and to neighbourhood effects especially through the probability of improving educational levels. Immigrants and refugees tend to concentrate in a few neighbourhoods in the bigger towns or cities with subsequent political tensions and social frictions.

Ireland and Great Britain share a common migration experience through the large Irish emigration to the British island. Ireland has traditionally been an emigration country, while the

12 The overview in this and the next section is based on the findings of two large international research teams directed by the author. Zimmermann (2004) collects country chapters of the major European countries and traditional immigration countries written by international experts that summarize the research findings in the literature for the years after World War II. Tranaes and Zimmermann (2004) and their authors study the recently collected micro data from a bi-national migration survey for Denmark and Germany. Both books deal intensively with work participation and earnings of the migrants as with their effects on the labor market performance of natives. 
United Kingdom has largely restricted immigration to people from its former colonies. Recently, and associated with the rising success of its economy, Ireland seemed to have benefited from the inflow of skilled people who have contributed well to the economy and assisted in reducing earnings inequality. While British migration is largely driven by economic incentives, the free flow of labour has been distorted by growing policy intervention. As a consequence, migration policy has become inextricably linked with domestic race relations policy. The ethnic minority population exhibits rising educational levels, especially in the second and subsequent generations. Labour market disadvantages seem not to reflect discrimination, but the slow assimilation process whereby immigrants can only improve their labour market status with length of residence.

Central Europe encompasses the traditionally attractive labour markets of Germany, Switzerland, Austria, the Benelux countries, and France. France has gone through similar phases of de-colonization and labour hiring as the Netherlands. French immigration policy has focused on people who were willing to accept the French language and culture. However, the majority of the immigrant population in France are manual workers and suffer from poor labour market conditions. The Dutch ethnic minorities are also in a disadvantaged socio-economic position. Cultural aspects, less functional social networks and human capital factors are likely culprits of the immigrants' plight or marginalization. While second-generation migrants are making progress, they are not fully integrated.

The most important Europe an immigration country is Germany, which similar to the Netherlands has been traditionally the port for many labour migrants. Germany, however, has also attracted substantial inflows of non-economic migrants such as relatives, refugees, and ethnic Germans from Eastern Europe. Ethnic Germans were generally found to assimilate, although at a slow rate. This has become more problematic with their recent immigration waves. Foreigners today are under more labour market pressures than natives. This is largely the consequence of occupational status, and not of behaviour. Self-employment is a channel for 
integration into the economy. There is no real indication that migrants depress native wages or increase their unemployment risk. Immigration effects are either small or insignificant, or they have a positive impact on the economic situation of the natives. ${ }^{13}$

For decades, the southern European countries like Italy, Greece, Spain, and Portugal were experiencing net outmigration. They are now in a process to become traditional immigration countries, receiving people from Northern Africa, the Balkans, and other less developed parts of the world mostly through illegal immigration. The available Italian research on the impact of foreign workers on the natives has provided only few cases of negative findings. There is even some evidence of a complementarity between migrants and natives, suggesting that immigration may actually improve the labour market conditions of the natives. If the relationship is negative, like in the llegal sector, the estimated effects are small and indicate a negligible economic importance. An exception is the illegal part in the agricultural sector where natives and migrants are strongly competitive. Illegal migrants in Greece are mostly in agriculture, but also in the construction and service industries. Studies show that foreign workers in agriculture largely took available vacancies and even generated their own jobs. Immigration did not raise the overall unemployment of natives, although in some selected industries such as construction and services there were some negative effects. Migration in Spain has become more internal, with a strong rise in intra-regional migration. This increase in migration is a response to the increased employment opportunities in the service sector in all Spanish regions. Although foreign immigration is still low in Spain as it is in Portugal, its size is growing strongly and it is rapidly gaining attention.

The lessons one can draw from the European experience are: In the past, the labour market integration of migrants has been slow, but steady. The impact on the natives has not been

13 This indicates that migrants are either weak complements to natives or they bring with them particular abilities that are either in excess demand or not available at all in the host country. See section 2 above for a more detailed analysis. 
very strong, but mostly beneficial. However, with globalisation and the particular pressure on low-skilled workers and the increased demands on high-skilled people, the nature of the game seems to change. The economic position of the new immigrants has become weaker. From this perspective, a selective immigration policy appears to be even more important than before.

\subsection{A Recent Comparative Study: Denmark versus Germany}

An international comparative research team studying the immigration experiences in Germany and Denmark using fresh survey data report the following findings $:{ }^{14}$ There are greater ethnic differences in Germany than in Denmark with respect to both educational attainment and vocational training. Immigrants in Denmark are less well educated upon arrival, but they acquire more schooling once they are in the country compared to immigrants in Germany. In comparison to natives, there is severe under-employment of immigrants in both countries. The employment rate is lower for non-Western immigrants in Denmark than it is in Germany, although natives are more attached to the labour force in Denmark than in Germany. Immigrants have a larger presence in the German labour market than in Denmark. This difference can be explained by the fact that immigrants in Denmark are less educated upon arrival, and that financial incentives to work are low in Denmark due to an unemployment benefit system that pays a higher replacement rate to the low-paid income groups. Education and vocational attainment are powerful determinants of labour market attachment in both countries.

Whereas immigrants in Denmark are less financially motivated to seek employment than their counterparts in Germany, once at work, they earn more throughout their working lives than comparable immigrants in Germany. Although experience is not as well rewarded in Denmark, an initial earnings advantage upon arrival is sustained. Human capital acquired in the host country generates an earnings premium in both Denmark and Germany.

14 See Tranaes and Zimmermann (2004) and Zimmermann and Hinte (2004). 
While Denmark seems to be a more attractive country for employed immigrant workers, Germany was found to offer better opportunities for entrepreneurs. Although the selfemployment rates are similar in both countries, self-employed immigrants in Germany are clearly positively self-selected, while those in Denmark seem to be more randomly allocated. Consequently, self-employed immigrants earn much more in Germany than in Denmark, and also much more than migrant wage earners in Germany. The Danish self-employed migrants earn less than the salaried group.

Immigrants induce redistribution through public sector finances whereby the net transfers in public contributions typically go from Western immigrants to the public sector, and from the public sector to immigrants from non-Western countries. This confirms that depending on the selection mechanism immigrants can contribute substantially to public sector finances or are a net burden, which supports the proposal to obtain more labour migrants. ${ }^{15}$ The employed redistribution efforts bring the average disposable income of Danish non-Western immigrants much closer to the disposable income of native Danes. The disposable income of Danish nonWestern immigrants is much higher than that of German non-Western immigrants. These Danish immigrants have almost the same distribution as native Danes, while the distribution of disposable income in Germany of migrants is much more unequal.

15 Two recent studies have provided some quantitative evidence based on the intergenerational accounting approach. Zimmermann and Hinte (2004) show that Germany still gains a lot from the guestworker generation. Calculated on the basis of 1996, they find that the net financial contributions of these migrants over their lifetime has a present economic value of 35,000 Euro per head. Germans, however, due to an unfavoural age structure are receiving net transfers with a present value of 14,000 Euro and gain substantially from redistribution. The available Danish data allow Zimmermann and Hinte (2004) to calculate on the basis of 2000 that Danes pay a net contribution with present value of 16,600 Euro per head, Western migrants pay 39,700 Euros, and non-Western migrants receive 142,900 Euros. Roodenburg, Euwals and ter Rele (2003) also find that the current non-Western migrants in the Netherlands turn out to be a burden to the public budget, whereas migrants with similar characteristics as the Dutch population are net contributors. Roodenburg, Euwals and ter Rele (2003) state (p. 81): "The results presented in this study are more negative about the fiscal impact of immigration than omparable studies for most other countries. Compared to the results for the United States and Germany, the differences mainly originate from the fact that labour market performances of immigrants in these countries do not lag as much behind those of natives as they do in the Netherlands." These numbers do not show that migration as such is a problem, they demonstrate that some past immigration and integration policies are problematic. 
It can be concluded that Germany is able to attract better educated immigrants than Denmark, get them into employment, and offer more to people with entrepreneurial talents. Denmark keeps more immigrants in the welfare system, but offers better remuneration to regular workers and some incentives for immigrants to educate themselves at higher levels - but not to undertake vocational training. The findings reported here also suggest that both countries could benefit quite considerably by executing more pro-active labour market recruitment and integration measures. Economic incentives seem to matter and a more selective immigration policy that generates more active labour market participants should be beneficial to the economy.

\section{Getting People to Work - the Challenge of the Lisbon Process}

In response to various concerns about the economic prospects of the European Union, the European Community has been implementing various political strategies. Among recent initiatives have been the Lisbon Agenda, which aims at making Europe by 2010 the most competitive and dynamic knowledge-based economy in the world, capable of sustainable economic growth, with more and better jobs and greater social cohesion; and Eastern enlargement, whose aim is to rapidly raise living standards in the new member states and to improve economic conditions in the European Union in general. Both initiatives have implications for migration and integration strategies. The Eastern enlargement process has caused debates about additional immigration from the East, since all labour markets will eventually have to open up to workers from the new member states. The newly agreed European Constitution also suggests that the social security systems of the host countries would take care of citizens from EU member states, which has created concerns about "country-hopping" and "welfare shopping".

The Lisbon Agenda states that employment and economic policies should aim at a rise of the overall employment rate in Europe to as close as possible to $70 \%$ of the population aged 15- 
64, and an increase in the employment rate for women to more than $60 \%$ (Lisbon targets). An agreement of the Stockholm European Council of 2001 sets intermediate targets for the employment rates in the EU in 2005 of $67 \%$ overall and $57 \%$ for females (Stockholm targets). In order to achieve these goals, the labour market implications of immigration have to be taken into account.

In June 2003, the European Commission adopted a "Communication on Immigration, Integration, and Employment" that studied immigration in the context of demographic change and proposed a strategy to promote the better integration of immigrants and to prepare for attracting more immigrants in the medium-term future. The need for such initiatives is suggested by the fact that even if the Lisbon targets are achieved by 2010, employment in Europe will start to fall significantly afterwards, due to the aging of the population as a result of demographic changes. Achieving sustained economic growth would require a greater increase in productivity than what can probably be achieved. It is, therefore, important to mobilize the current stock of migrants to enter the labour market, and to prepare for new immigration by implementing better integration strategies.

How far is the Lisbon Agenda on its way and to what extent are its goals likely to be achieved for immigrants as well as others? The employment rates for $2002^{16}$ suggest that the European Union is still far from reaching these goals. Increases of about 6 percentage points for the total EU employment rate (from $64.3 \%$ in 2002) and about 4 percentage points for the female EU employment rate (from 55.6\%) have to be materialized to ensure that the targets are achieved. EU-national immigrants exhibit overall higher employment rates $(66.4 \%$ in total and $58.8 \%$ for females), and are hence closer to the employment goals. This also suggests that their mobility is driven largely by the desire to work. However, non-EU national immigrants have exceedingly low employment rates. Unlike EU nationals, they are not well integrated into the

\footnotetext{
16 See for the numbers here and in the following European Communities (20 03).
} 
labour markets. Employment rates are around 50\% for the total non-EU immigrant population, and around $40 \%$ for females. There is a substantial integration problem with respect to non-EU nationals in the European labour markets. Another marginalized group in Europe are the lowskilled. Including foreigners and natives, their total employment rate in the EU is only $49 \%$. Low -skilled natives and non-EU nationals compete for jobs. The mirror picture is provided by the unemployment statistics: EU national migrants exhibit a rate of $7.1 \%$ which is marginally below the $7.7 \%$ for the EU in total. Non-EU nationalmigrants have a high unemployment rate of $15.8 \%$, which is even much higher than the $10.8 \%$ of the European uns killed.

This investigation has identified three important issues: First, the success of the Lisbon Agenda will depend mainly on the ability to provide jobs for the low-skilled. (The employment rates of the medium-skilled (70.5\%) and the high-skilled (82.8\%) already fulfill the $70 \%$ rule.) It will also help to get more females into work, but the deficits with respect to the Lisbon goals are much smaller for females than for the low -skilled. Second, non-EU national migrants are largely underemployed This integration problem is not only socially unsustainable, but also economically irrational. If more is done to attract the low-skilled population in general to enter employment, this may also help the non-EU national migrants since they are largely low-skilled. However, an even more active integration policy with early training measures is desirable to attract non-EU nationals into work. Third, in the face of the current and probably rising deficits in skilled workers in the medium term, a selective immigration policy could help to reduce the inflow of low -skilled people and to obtain a creditable position on the international labour markets for high-skilled and well-trained workers.

\section{Conclusions and Policy Discussion}

Many European labour markets are characterized by two seemingly contradictory trends. On the one hand, employers complain about a lack of skilled labour. On the other hand, the statistics 
measure a high level of unemployed workers, typically low-skilled people. There are no indications that this will remain a short-term phenomenon; to the contrary, it is expected to continue and become even more marked. This indicates coordination deficiencies on the labour market. The qualification structure supplied by the workers does not change as rapidly as the qualification requirements by the companies in the long-term process of structural change in the economy. At the same time, the for eseeable demographic trends will bring additional burden to Europe and will alter the society radically over the next few decades. An ageing population and a decline in its size will not leave the labour market unaffected. The growing age of the resident working population will lead to a shortage of young, highly qualified and suitable employees. ${ }^{17}$ A number of strategies are available to prepare proper policy responses. ${ }^{18}$

\subsection{Where Do We Stand Now?}

Given the need to survive in highly competitive international markets with high innovative activity, it is an attractive strategy to execute a selective immigration policy to attract the highly qualified workers needed in innovative industries. However, such a strategy is nowhere systematically employed in Europe. Hence, it is not surprising to observe that employment of migrants is relatively weak in export-oriented, research-intensive industries. Migrants are more attracted to those industries that face high import competition and employ less qualified workers. The competitive effects of this type of immigration are ambiguous. Some have concluded that an influx of cheap low-quality labour may lead to a loss of competitiveness of the host country in the long-run, since it induces a slow-down in the adjustment process from

17 Some argue that aging will lead to a shortage of low-skilled labour because of the increasing demand for health care services. While I agree that the health-care sector is a central future market that also attracts low skilled people, there are some doubts that this will be enough to employ the low-skilled workers. The sector will certainly attract also a larger share of the risingly needed high -skilled employees. The predictions for the low-skilled and the high-skilled workforce in Germany for the next decades provided in Zimmermann, Bauer, Bonin, Fahr and Hinte (2002) suggest that there will be excess demand for the high-skilled and excess supply for the low-skilled workers at a rising level.

18 The following discussion has benefited from the author's participation in the preparation of a report to the immigration committee headed by Rita Sißmuth that had supported the new German Immigration Law. See Zimmermann, Bauer, Bonin, Fahr and Hinte (2002). A revised draft with an evaluation of the new German immigration law will appear in English as Zimmermann, Bauer, Bonin, Fahr and Hinte (2004). 
low-quality production to high-quality production. However, declining relative wages for lowquality work are incentives for the native population to engage more in human capital formation to earn higher wages in the long-run.

Economists are tempted to advocate that the labour market should determine the size of immigration. Whatever the virtues of this approach are in principle, the social frictions created by immigration require an active policy for selecting immigrants and integrating them into the country, even when the problem of the existing persistent unemployment is ignored. The benefits of migration can only be reaped if the adjustment costs are addressed. If there are substantial immigration costs for the receiving countries, they can be compensated by imposing financial constraints on migrants to share the burden. From the view of many citizens in the destination countries, immigrants compete with the natives for scarce goods that "belong" in some sense to the citizens of a country. Being a citizen of a state is like membership in a club. As clubs, states may decide to request entry fees in some form from new members. Such instruments can be also used to regulate the immigration flows.

It has been pointed out that immigration can successfully increase the flexibility of the labour market, provide incentives to slow down wage growth, and thus allow more people to obtain gainful employment. Immigrants are typically more flexible than natives. They may ease labour shortages in areas in which natives do not want to work and even create their own work opportunities. As they tend to be more responsive to labour market conditions than native workers, immigrants may help to smooth the adjustment of labour markets to regional differences or shocks. The increase in human capital that can be achieved by a selective immigration strategy can also contribute to long-run growth. However, in many countries there are strong differences in the economic performance of EU and non-EU migrants. ${ }^{19}$ Given these

\footnotetext{
19 See the findings reported in section 3.4.
} 
possible gains, more openness of the European Union towards non-EU labour migration seems desirable , but also an economic approach to determine a more selective entry policy is required What kind of immigration is required depends on the particular economic situation. For instance, in the glden 1960s with full employment in the labour markets and a need for lowskilled workers, many Northern European countries were attracting blue-collar immigrants. Today, with the painful institutional constraints on the low-skilled labour markets and excess demand for skilled workers, the situation is more complicated: Since there is high unemployment among the low skilled due to institutional constraints like union wages, more unskilled migrants are only acceptable if there is proven evidence that they are willing to work, and their presence will make this market more competitive and hence add additional jobs for the natives through reduced wages. More promising are additional skilled immigrants: since they are in demand, the wages in the skilled labour market will not rise, but their employment will cause additional demand for native unskilled. Due to unemployment among the unskilled, their wages will remain constant. All in all economic immigration, properly organized, allows the economy to expand production with moderated wage growth.

Those concerned about immigration sometimes suggest that the European economy might adjust in other ways. For example, it is sometimes argued that free trade and free capital mobility could replace free labour mobility. In other words, encourage potential migrants to work and export from their own countries. However, a substantial part of goods and services produced are non-tradable. Import competition due to cheap or high quality labour abroad may also crowd out native workers, and foreign investment may have a similar impact. Controversial outsourcing strategies of jobs are already discussed or even prepared in many companies across Europe. Fostering free trade and free capital mobility is a good long-term strategy for economies to establish welfare that will neither stop short-term migration pressures nor could those strategies be implemented at short notice. A more flexible immigration policy would 
nevertheless help to keep the production of goods and services in Europe and to be better prepared for the future international competition.

Another argument is that immigration pressures due to differences in economic development could best be moderated by rapid domestic economic growth in the sending countries, thus advocating the need for economic transfers and development policies. However, the available evidence in developing countries suggests that a larger rate of development often destabilizes the economic system and creates new options for short-run out-migration. Allowing people from foreign nations to work in Europe enables them to train their human capital, send remittances home, intensify economic relationships between the host and the home countries and eventually return home. Labour migration is to a large extent rela ted to future return migration, as long mobility is not restricted. A filter effect can be observed: The more successful people stay, while the less successful move on. Hence, through a better world-wide allocation of resources and more flexible strategies to adjust and build up economies through migration, human capital building, remittances, and more intensified economic relationships, both the sending and the receiving countries will gain.

Other strategies are proposed to deal with the declining work-force in Europe over the next decades, like mobilizing the unemployed and the female workforce, or increasing the retirement age and human capital investments. When concerns are raised about whether some of the marginal groups will provide the skill profile needed on the labour markets, it is suggested that the government could train and retrain the workforce. While these efforts are viable, to some extent, they are also long-run options with uncertain effects. For instance, even if women work as frequently as men in Germany, a country with very low female work participation and large demographic changes to come, the long-term decrease in the working population can only be temporarily slowed down. But to achieve these increases in female work participation, a radical reform of the child care and training systems has to be successfully carried out first. Similar considerations apply to a policy of increasing the retirement age. Such a strategy would produce 
a singular and possibly substantial short-term effect on labour supply which would, however, not reverse for long the decrease in the size of the resident working population.

One may question the need to stabilize the size of the workforce in a country, because there is no such thing as an optimal population size from an economic viewpoint. After some (may be considerable) time of adjustment, the economy will function around a lower or higher level. However, it is the adjustment process that creates painful pressures and that needs to be avoided. An ever falling native population causes a problem, because the economy could never adjust at a new and lower level. Hence, the European Union needs to prepare a unified policy of selective labour immigration, to channel and coordinate the flows of immigrants that are almost certainly coming and to generate the supply of skilled migrants that is so much needed. Past labour market experiences regarding immigrants have been rather beneficial, with no dramatic effects on native unemployment and wages. Even in the face of unemployment, immigration might be beneficial for society as a whole since it may erode institutional constraints on the labour market.

Migration, however, is not the ultimate solution to the aging problem since its cause, fertility decline, is not likely to get reversed due to the typically observed adjustment of migrant fertility to the standards of the natives. Also a strongly growing share of migrants can cause integration problems and social tensions. The migration option is powerful to moderate for some time the demographic adjustment pressure but it should be employed in a package of alternative responses. The best strategy is to smooth the adjustment process employing all available strategies including immigration.

\subsection{A Conceptual Framework for Migration Policy}

Migration policy is still largely under the control of the European Union member countries. However, due to the free labour, capital and product markets within the union (with some temporary constraints in a transition period for the new member countries), there is a need to harmonize the single-country migration policies across Europe. An economic migration policy 
should be part of a strategic policy that supports the creation of a flexible and integrated European labour market. Currently, there are mobility restrictions for non-EU migrants and country-specific immigration rules for them. An inflow of non-EU labour immigrants in one country may affect the economies in all European Union partner countries through illegal flows, forced mobility of the natives, or adjustments through the capital and goods markets. If the necessary adjustments do not take place or if they are slow, then this will create economic inefficiencies.

Negative economic effects of such a policy in one country might call for policy coordination. For instance, if imported labour in the host country leads to the production of cheaper or better products, this will improve the competitive position of that country on the European markets. Consequently, the rise in imports in the EU partner countries will create competition with locally produced goods, losses in their market share and unemployment among the natives. Hence, any active and selective economically motivated immigration policy of one member country would harm the partner countries (as a devaluation policy would do in a world of fixed exchange rates). Current immigrants into Europe are mostly not economically motivated and they are, if at all, an economic burden for the host country; they are either economically inactive or they face high risks of unemployment since they have not the needed labour market qualifications. This explains why there is currently no strong political pressure to coordinate economic immigration at the European level. It will, however, change as soon as some larger member countries like Germany will employ an economic immigration channel.

Under the current constraints on the mobility and working possibilities of non-EU migrants, it would be best if natives would move in response to immigration and act as a flexibility reserve. However, internal EU mobility is low and there might be virtues of immobility like substantial firm-specific human capital or strong preferences to remain in local social networks. Even the formation of the European Common Market was unable to stimulate mobility significantly. It would, therefore, be the most profitable strategy if the legal constraints 
on non-EU migrants (and the temporary ones on natives from the new member countries) would be removed quickly to create a flexible pool of young, educated and highly-skilled workers. These mobile workers w ould ensure for some time efficient adjustment and the creation of larger welfare across all EU member states.

Sometimes it is also argued that harmonization of immigration policies would not allow single countries to execute their preferences for generous welfare systems. To the contrary, an economically motivated immigration policy would avoid migrants that are at risk to take up welfare benefits, and would seek to attract individuals who are easily integrated into the economy.

From this discussion follows that it is necessary to develop a joint European legal framework that guides the individual countries' migration policies. An EU-wide quota for temporary and permanent visas would allow to fix the annual inflow of economic migrants at the political level. Europe needs to become an active player in the international labour markets. To develop an immigration policy with economic objectives, it is important to understand that the demand of an immigration country for immigrants with defined characteristics is part of a "market" in which supply is self-selected. If the immigration policy is to attract the immigrants most valuable to the immigration country on a market in which a number of nations compete for skilled labour, the institutional legal settings applicable to migrants must be competitive with institutional settings in other countries, especially those who are currently seen as immigration countries.

The immigration policy to be developed must further account for the economic effects of migration. The degree to which immigrant labour is complementary to or a substitute for resident labour determines the degree to which resident labour benefits as a result of labour immigration. Labour immigration will have negative consequences for a resident labour force that compete s for the same jobs as the immigrants. If immigrants can be substituted for resident labour, displacement effects can occur and result in unemployment. If, on the other hand, immigrants 
contribute particular qualifications or fill existing vacancies, the economy and the working population will benefit. If migrant labour is even complementary to resident labour, immigration will improve the productivity of the resident working population and increase demand for their services. Unemployment will as a result decline. It is therefore a crucial responsibility of immigration policy to select migrants who will generate the most benefits for the national economy and are likely to enhance employment opportunities for the resident labour force.

Long-term and short-term immigration objectives may differ. In the long run, the foreseeable population decline suggests a larger need for immigrants even if other measures such as the mobilization of female labour, the increase of the retirement age, and better education and training strategies were implemented. In the short term, less additional net immigration is needed. However, the profile of the current migrant stock can be changed to increase the share of people at work by increasing work incentives internally and by introducing a selective economic immigration policy for the new immigrants. The inflow of migrants for humanitarian and other undebatable legal reasons has become smaller recently. ${ }^{20} \mathrm{~A}$ large number of immigrants, especially if they are economically active in the labour market, will eventually return home if labour mobility is free. The temporary immigration policy could distinguish between labour immigration in professions in short supply, the immigration of executives of multinational companies and researchers, student immigration and special cases.

This points out the need for a dual strategy for the efficient allocation of immigration rights that would result in a higher welfare in comparison to current migration policy. Such a strategy addresses both the supply and the demand of the labour market and is designed to select

20 This is also the consequence of a more effective control of non-economic immigration. Take Germany as an example: Over the last decades the average annual inflow was 700,000 and the average annual outflow was 500,000 people, leaving a net inflow of 200,000. The number of immigrants who could be selected by an active labour immigration policy has increased to some 400,000 in recent years as a result of the decrease in ethnic Germans, asylum seekers and refugees entering Germany, and is likely to increase further. Since net immigration should rise to about 300,000 annually in the near future to compensate for demograp hic losses, and since return migration in the future should rise with a larger number of economic migrants in the country, more than 500,000 people entering Germany per year could be considered in the context of economic immigration. 
potential migrants with the highest value for the immigration country and jobs where the recruitment of an immigrant offers the highest benefits. An administrative process would appear to be the preferredchoice for the selection of permanent immigrants. Such immigrants should be selected using observable and measurable criteria and preference should be given to better qualified applicants. Administrative processes for allocating permanent immigration rights are widely used around the world as are top-down selection processes which are implemented by point systems in several traditional immigration countries. Empirical studies have shown that the average qualifications of immigrants granted permanent residence visas by countries operating under point systems is higher than that of immigrants into the United States where immigration is not controlled by economic criteria. Hence, a properly designed point sys tem is able to impose the required labour market criteria on the inflow of migrants. This observation should affect European immigration management.

A more detailed review of administrative practices in Canada, Australia and New Zealand demonstrates that the point systems operating in these countries may have fundamental features in common, but still vary substantially mainly regarding the rating of migrant characteristics. For instance, Australia puts, in contrast to the other countries, some weight on indicators of temporary hbour demand. Remarkable differences also exist with respect to the integration of the migrant family which has always been given substantial weight in Australia and New Zealand, but was, until recently, disregarded in Canada. The design of a point system thus allows for much flexibility.

Any economically motivated long-term immigration strategy should make a distinction between skilled labour, nvestors and business immigrants. Business immigrants and investors create opportunities for employment and income and should therefore be highly welcome. Permanent labour immigrants should be primarily selected by a point system. It should be a tool to select immigrants in accordance with demographic and economic needs. It will be necessary to define minimum requirements including above all a maximum age, minimum qualifications 
and adequate financial resources for an initial period in the country. A language test should be mandatory and a failure of the test could trigger an obligation of the immigrant to pay a security deposit which would be reimbursed following the successful completion of language tuition in the host country. In the point system, priority should be given to criteria such as age, education, qualifications and work experience or a prior firm job offer. Integrational elements to be addressed by the point system include prior stays in Europe, relatives living in Europe, accompanying children and above all language skills. Applicants should be required to achieve a minimum score to be considered for permanent immigration. As immigration is permanent, an appropriate immigration program should be arranged based on a "integration contract" relationship between the immigrant and the society of which the immigrant will be a member. A European-wide quota on permanent migrants would allow fixing the number of permanent visas at the political level.

The immigration of investors and business people should be approved directly outside the point system. Investor immigration should exclusively be governed by the sum invested. For business people, on the other hand, who invest into a new or an existing business, the development of the business should be reviewed regularly. Student immigration should be facilitated to create early ties of highly qualified young persons in Europe. The selection of undergraduates should be left entirely to universities. Strict local native language requirements are not so important, but the academic courses should be taught in English. After graduation, student immigrants should have the right to obtain permanent residence if they have a concrete job offer. Immigrants taking up firm traineeships or apprenticeships should also be allowed to enter the country under the student program.

The urgent need for short-term skilled labour should be accommodated by establishing a non-bureaucratic system for temporary immigration. Unfortunately, it is very difficult if not impossible for a public administrator or an outside observer to identify the real short-term needs of the business community. Hence, an auction system operating among interested companies for 
the allocation of immigration certificates would appear to be the best choice to satisfy temporary immigration needs. These certific ates would entitle the company to recruit an immigrant on the world market for a job for a defined period of time. Such an auction system translates relative labour market shortages into relative bid prices. Existing shortages would become transparent and excess demand would show where further policy response is necessary. Since companies would have to pay for the right to hire a worker, a share of the immigration gains would be given to the public coffers. A European-wide quota on temporary migrants would allow fixing the number of temporary visas at the political level.

An auction system is superior to alternatives such as a fee system mainly as it matches supply and demand more efficiently. Companies will only be willing to purchase at an auction if they are unable to satsfy their demand on the regular local labour market. The objective of the auction can be underscored by a minimum bid requirement. There is no need to formally verify the non-availability of native labour. The certificates should be limited to a period of three years, and could be potentially renewable for the same person. Temporary immigrants should have the right to be accompanied by their family members, and spouses should be entitled to a work permit. During their employment under this programme, temporary immigrants should have the right to apply for permanent immigration under the point system. Such an arrangement would create an appropriate link between the temporary and the permanent immigration systems.

A problematic case is the relationship between economic and non-economic immigration, especially asylum seekers. ${ }^{21}$ It is possible to design a joint system for asylum seekers and immigrants where immigrants are ranked according to an economic point system and asylum seekers are awarded humanitarian points on a scale according to the gravity of their circumstances. Only those in both groups reaching the minimum point score are admitted. Policy makers would have to decide on the appropriate structure of the point system, the minimum

21 See Hatton (2004) and Zimmermann (1995a) for this issue. 
thresholds, and an overall quota for both groups. Then actual relative supply of applicants would determine the allocation of the entry permits.

\section{Policy Conclusions}

European Union economies are pressed by two seminal challenges: A demographic change that induces population ageing and a decline of the workforce, and a split labour market that is characterized by high levels of unemployment for low -skilled people and a simultaneous shortage of skilled workers. This lack of flexible high-skilled workers and the aging process has created the image of an immobile labour force and the eurosklerosis phenomenon. Mobility ensures the best allocation of resources, and hence economic efficiency. But in the face of local or firm-specific human capital and individual preferences to remain in stable social networks immobility has also virtues. In such a situation, an economically motivated European immigration policy can generate high welfare improvements. A selective policy that discourage s unskilled migrants and attracts skilled foreign workers will vitalize the labour market, foster growth and increase demand for unskilled native workers. Their wages will increase and their unemployment rates will decrease, respectively. When migrants are different, when they bring variety in the labor market and improve the host country's ability to speedily adjust the economy to its long-run needs, they are of invaluable help. Note that while immigration has many dimensions (including social and humanitarian), this paper deals with the issue from a purely economic perspective.

There is a need to harmonize the single -country migration policies across Europe. Crucial is to determine a European-wide quota for economic non-EU immigrants and to allow them to be fully mobile. This will help to create a flexible and integrated European labour market. Currently, there is free labour mobility of EU natives (with a transition period for people of the new member states), but mobility restrictions for non-EU migrants and country-specific 
immigration rules for them. An inflow of labour immigrants in one country may affect the economies in all European Union partner countries through illegal flows, forced mobility of the natives, or adjustments through the capital and goods markets. If the necessary adjustments do not take place or if they are slow, this will create economic inefficiencies. Under these conditions, it would be best if natives would move. However, internal EU mobility is low and even the formation of the European Common Market has not significantly stimulated it. It would, therefore, be beneficial if the legal constraints on non-EU migrants (and the temporary ones on natives from the new member countries) would be removed quickly to ensure efficient adjustment and larger welfare across all EU member states. It is further necessary to develop a joint European legal framework that guides the individual countries migration policy activities.

Europe needs to become an active player on the international labour markets. The European Union has to set European-wide quotas for net immigration on a permanent and temporary level. Long-term or permanent immigration should be governed by the introduction of a point system at the European level. It should be a tool for selecting immigrants in accordance with demographic and economic needs. In the point system, priority should be given to criteria such as age, education, qualifications, language skills and work experience or an existent firm job offer. Short-term or temporary immigration is best organized through an auction of workpermits among interested companies. Through this process, the companies would not only reveal their real preferences for foreign workers, but also contribute a share of the immigration gains to the public coffers. 


\section{References}

Bauer, T., B. Dietz, K.F. Zimmermann and E. Zwintz (2004) "German Migration: Development, Assimilation, and Labour Market Effects", in Zimmermann, K. F. (ed.) European Migration: What Do We Know?, Oxford: Oxford University Press.

Bauer, T., M. Lofstrom and K.F. Zimmermann (2000) "Immigration Policy, Assimilation of Immigrants and Natives' Sentiments Towards Immigrants: Evidence from 12 OECD Countries", Swedish Economic Policy Review, 7, 11-53.

Bauer, T. and K. F. Zimmermann (1997) "Integrating the East: The Labor Market Effects of Immigration", in S.W. Black (ed.) Europe's Economy Looks East - Implications for Germany and the European Union, Cambridge: Cambridge University Press, 269-306.

Boeri, T., G. Hanson and B. McCormick (2002) Immigration Policy and the Welfare System, Oxford: Oxford University Press.

Bover, O. and P. Velilla (2004) "Migrations in Spain: Historical Background and Current Trends", in Zimmermann, K. F. (ed.) European Migration: What Do We Know?, Oxford: Oxford University Press.

Borjas, G. J. (1994) "The Economics of Immigration", Journal of Economic Literature, 32, 1667-1717.

Brücker, H., G. Epstein, B. McCormick, G. Saint-Paul, A. Venturini and K.F. Zimmermann (2002) "Managing Migration in the European Welfare State", in T. Boeri, G. Hanson and B. McCormick (eds.), Immigration Policy and the Welfare System, Oxford: Oxford University Press, Part I, 1-167.

European Communities (2003) Employment in Europe 2003. Recent Trends and Prospects. Luxembourg: Office for Official Publications of the European Communities.

Faini, R., G. Galli, P. Gennari and F. Rossi (1997) "An Empirical Puzzle: Falling Migration and Growing Unemployment Differentials Among Italian Regions", European Economic Review, 41, 571-579.

Faini, R., J. de Melo and K.F. Zimmermann (1999) Migration. The Controversies and the Evidence, Cambridge: Cambridge University Press.

Hatton, T. J. (2004) "Seeking Asylum in Europe", Economic Policy, 38, 5-62.

Obstfeld, M. and G. Peri (1998) "Regional Non-adjustment and Fiscal Policy", Economic Policy, 26, 207-247.

OECD (1994) The OECD Jobs Study: Facts, Analysis, Strategies, Paris: OECD.

Roodenburg, H., R. Euwals and H. ter Rele (2003) Immigration and the Dutch Economy, The Hague: CPB Netherlands Bureau for Economic Policy Analysis.

Tranaes, T. and K. F. Zimmermann (2004) Migrants, Work, and the Welfare State, Odense: University Press of Southern Denmark.

Venturini, A. (2004) Post-War Migration in Southern Europe. An Economic Approach, Cambridge: Cambridge University Press.

Zimmermann, K. F. (1995a) "European Migration: Push and Pull", Proceedings of the World Bank Annual Conference on Development Economics 1994, World Bank Economic Review, and World Bank Research Observer, 313-342.

Zimmermann, K. F. (1995b) “Tackling the European Migration Problem”, Journal of Economic Perspectives, 9, 45-62.

Zimmermann, K. F. (1998) "German Job Mobility and Wages" in I. Ohashi and T. Tachibanaki (eds.), International Labour Markets, Incentives and Employment, Houndmills: Macmillan Press, 300-332.

Zimmermann, K. F. (2004) (ed.) European Mig ration: What Do We Know?, Oxford: Oxford University Press.

Zimmermann, K. F. and T. Bauer (2002) (eds.) The Economics of Migration, Vol. I - IV, Cheltenham/Northampton: Edward Elgar Publishing Ltd. 
Zimmermann, K. F. and A. Constant (2004) (eds.) How Labor Migrants Fare, Berlin et al.: Springer-Verlag.

Zimmermann, K. F., T. Bauer, H. Bonin, R. Fahr, and H. Hinte (2002) Arbeitskräftebedarf bei hoher Arbeitslosigkeit. Ein ökonomisches Zuwanderungskonzept für Deutschland. Berlin, et al.: Springer-Verlag.

Zimmermann, K. F., T. Bauer, H. Bonin, R. Fahr, and H. Hinte (2004) Migrant Labor Demand in the Face of High Unemployment. An Economic Immigration Concept for Germany. Berlin, et al.: Springer-Verlag.

Zimme rmann, K. F. and H. Hinte (2004) Zuwanderung und Arbeitsmarkt. Wie erfolgreich sind ausländische Arbeitskräfte in Deutschland und Dänemark? Berlin, et al.: SpringerVerlag. 